\title{
The effect of organic matter (OM) quality on the redox stability of OM-Fe association in freshwater sediments
}

\author{
Nana O.-A. Osafo* ${ }^{1,2}$, Jiř́ Jan ${ }^{1,3}$, Petr Porcal ${ }^{1,2,3}$, Daniel A. Petrash ${ }^{1,4}$, Jakub Borovec ${ }^{1,2,3}$ \\ ${ }^{1}$ Soil and Water Research Infrastructure, Biology Centre CAS, České Budějovice, Czech Republic \\ $5 \quad{ }^{2}$ Faculty of Science, University of South Bohemia, České Budějovice, 370 05. Czech Republic \\ ${ }^{3}$ Institute of Hydrobiology, Biology Centre CAS, České Budějovice, 370 05, Czech Republic \\ ${ }^{4}$ Department of Environmental Geochemistry and Biogeochemistry. Czech Geological Survey, Prague, 15200 Czech Republic
}

Correspondence to: Nana O.-A. Osafo (nana.osafo@bc.cas.cz)

Abstract. Redox sensitive iron (Fe) oxyhydroxides participate in the biogeochemical cycling of nutrients and trace metals.

10 Their co-precipitation with organic matter $(\mathrm{OM})$ leads to environmentally relevant OM-Fe associations. The stability of OM in such associations is still uncertain. It has been proposed that OM either increases the stability of the complex against reductive dissolution or enhance the dissolution (both abiotic and biotically) of Fe oxyhydroxides. The OM character, in terms of specific functional groups binding to Fe, could be a critical factor determining the fate and stability of OM-Fe. Here, sediment samples from a vertical profile of a mesotrophic freshwater reservoir were treated using a sequential extraction

15 scheme designed to distinguish Fe oxyhydroxides of different redox reactivity based on dissolution kinetics. To assess the reactivity and stability of the complexes, special attention was payed to the determination of redox active vs. stable fractions of $\mathrm{Fe}$ and the corresponding dissolved organic matter (DOM) components sequentially extracted. The quality of the extracted DOM was evaluated using UV-VIS and fluorescence spectroscopy together with the PARAFAC model. A selectivity model was used to ascertain the quality of OM preferentially associated with the different redox stable Fe oxyhydroxides.

20 Accordingly, we found that humic-like substances render the OM-Fe associations redox labile, while non-humic substances enhance the stability of the associations. These findings improve the understanding required for predicting the fate of $\mathrm{OM}-\mathrm{Fe}$ associations in freshwater sediments with different organic matter sources and characters.

\section{Introduction}

Organic matter $(\mathrm{OM})$ in lacustrine and soil ecosystems influences the coupled biogeochemical cycles of nitrogen $(\mathrm{N})$ and iron

25 (Fe), as well as trace metal bioavailability. The association of OM, Fe and aluminum (Al) oxyhydroxides prevents the microbial degradation of OM and enhance its stabilization in both soils and sediments (Kaiser and Guggenberger, 2000; Keil et al., 1994; Lalonde et al., 2012; Mikutta et al., 2007; Nierop et al., 2002; Torn et al., 1997; Wagai and Mayer, 2007) From these associations, Fe oxyhydroxides are of paramount interest because their reductive dissolution is intrinsically linked to other biogeochemical cycles, including those of carbon and phosphorus.

30 The affinity of OM toward Fe and the stability of the resulting organometallic complex is driven by several factors, with the most relevant being the structure and composition of the OM involved (Kellerman et al., 2015; Du et al., 2018; Han et al., 2019). Also important is the variable redox sensitive nature of Fe oxyhydroxides, with some of them being relatively more 
https://doi.org/10.5194/bg-2020-296

Preprint. Discussion started: 14 September 2020

(c) Author(s) 2020. CC BY 4.0 License.

(c) (i)

soluble, and thus generally referred to as the active pool, while others, displaying a more stable soluble behavior are known as the less active pool. The latter could play a major role in stabilizing the OM and Fe association both in soil and sediments (van

35 der Zee et al., 2003; Keil and Mayer, 2014). OM being heterogeneous in composition and redox behavior (Neff and Asner, 2001) also adds to the complexity of efforts aimed at fully characterize and understand the nature of the OM-Fe association. Components of dissolved organic matter (DOM) that could increase its redox reactivity include quinone-hydroquinone moieties as these engage in the shuttling of electron with Fe oxyhydroxides (Aeschbacher et al., 2010; Garg et al., 2015; Klapper et al., 2002; Klüpfel et al., 2014; Scott et al., 1998; Struyk and Sposito, 2001).

40 The co-precipitation and, in general, the complexation of OM and Fe oxyhydroxides at transitional redox boundaries usually leads to the formation of inner sphere interactions (Keil and Mayer, 2014). Such interactions could result in the transformation of iron mineral phases to more crystalline structures, which may ultimately lead to conditions prone to the preservation of the organic matter (Eusterhues et al., 2008; van der Zee et al., 2003). Due to the heterogeneous structure of OM, there have been different conclusions in terms of which specific component determines or favor its co-precipitation/adsorption with $\mathrm{Fe}$ oxyhydroxides and their subsequent stabilization in soil and sediments (Lalonde et al., 2012; Adhikari et al., 2017; Adhikari and Yang, 2015; Du et al., 2018; Han et al., 2019). Identifying the organic matter component that more effectively stabilizes an OM-Fe complex is crucial for elucidating its fate. The OM-Fe complex has both been argued to form a rusty carbon sink in anoxic sediments (Lalonde et al., 2012) as well as responsible of inducing the cycling of elements such as N, P and As, which are interlinked to the dissimilatory reduction of Fe (Borch et al., 2005; Xiao et al., 2016).

50 To understand which organic compounds are selectively preserved by the OM-Fe association, a number of studies have used either synthetic OM or Fe-oxyhydroxides (Du et al., 2018). Few others have used natural sediments that were characterized by applying an extraction protocol that selectively dissolves the OM associated with Fe oxyhydroxides using dithionite as the extractant (Lalonde et al., 2012; Wagai and Mayer, 2007). However, essentially missing in all the previous analytical approaches is the definition of the variable reactive Fe pools (in terms of the redox lability) present in the sediment/soil

55 fractions evaluated.

Here we use an easily accessible and economic method to determine which OM components contribute to redox stability of Fe-OM associations in natural aquatic environments. We applied a sequential extraction scheme proved to dissolve the different natural Fe pools in terms of redox lability (active vs. more stable) Fe-oxyhydroxides (e.g., Jan et al., 2015) followed by spectroscopic characterization approaches of DOM that include UV-VIS and fluorescence techniques. In addition, we compared bulk extractions to point out the advantage of sequential scheme in identification of the effect of OM quality.

\section{Materials and Methods}

\subsection{Site description}

Landstejn reservoir is a mesotrophic freshwater system located at the southern Bohemian region of the Czech Republic that serves as a potable water supply. The reservoir has a volume of $3.12 \times 10^{6} \mathrm{~m}^{3}$, with a $25 \mathrm{~m}$ maximal depth and surface area of 
https://doi.org/10.5194/bg-2020-296

Preprint. Discussion started: 14 September 2020

(c) Author(s) 2020. CC BY 4.0 License.

(c) (i)

$650.4 \mathrm{~km}^{2}$. Its annual average flow is estimated to be $0.09 \mathrm{~m}^{3} \mathrm{~s}^{-1}$. The reservoir is surrounded mainly by forest and minor settlements.

\subsection{Sampling}

Four different sediment cores were obtained along longitudinal transects defined from the tributary to the dam section by using a gravity corer. Sediment cores were transported in the dark at $4{ }^{\circ} \mathrm{C}$. Sediments were sliced in the laboratory into different

70 vertical layers, i.e., $0-0.5 \mathrm{~cm}, 0.5-1 \mathrm{~cm}, 1-2 \mathrm{~cm}, 4-5 \mathrm{~cm}$ and $10-12 \mathrm{~cm}$. Sediments were homogenized and dry mass $\left(105^{\circ} \mathrm{C}\right.$, $2 \mathrm{~h}$ ) as well as loss on ignition (LOI, $550^{\circ} \mathrm{C}, 2 \mathrm{~h}$ ) were determined. The proportion of dry mass increased along the vertical layers while the proportion of organic matter decreased marginally from the 2-12 cm layers, being more stable in the first 2 $\mathrm{cm}$ of the sediment pile.

\subsection{Sediment extractions}

75 First, each sediment sample was extracted sequentially following Jan et al. (2015) except for the HCl extraction step. Second, the samples were extracted using a bulk scheme (Fig. 1). The DOM extracted from water, the fractions from bicarbonate dithionite - a reducing agent, and the two fractions from $\mathrm{NaOH}$ are hereafter referred to as $\mathrm{H}_{2} \mathrm{O}, \mathrm{BD} 1$ and $\mathrm{BD} 2, \mathrm{OH} 1$ and $\mathrm{OH} 2$ respectively (Fig. 1). Fe is analyzed in the BD extracts. Differences in concentrations obtained in the sequential steps BD1 and $\mathrm{BD} 2$ and $\mathrm{OH} 1$ and $\mathrm{OH} 2$ are based on dissolution kinetics of both Fe and Al oxyhydroxides and their extraction efficiency (Jan

80 et al., 2015). Accordingly, the amorphous/poorly crystalline oxyhydroxides are dissolved in the shorter time steps (BD1, OH1), with the Fe extracted by BD1 being redox active, whilst the crystalline/stable oxyhydroxides were redox stable and dissolved in the longer time steps (BD2, OH2). In consequence, the Fe extracted by BD2 is referred to hereafter as less active. It must be noted, however, that a bulk sediment extraction with the longer time steps is not able to fractionate poorly crystalline from crystalline as it is the case in sequential extraction (Jan et al., 2015). Each of the mixtures were centrifuged at $3000 \mathrm{~g}$ for 10 85 minutes. The supernatant was then filtered using a $0.4-\mu \mathrm{m}$ pore size glass fiber filter (MN GF-5, Macherey-Nagel, Düren, Germany). Extracts from (BD) were acidified to $\mathrm{pH}$ ranging from 3 to 5 units to keep the $\mathrm{Fe}$ in the dissolved form and then aerated for $2 \mathrm{~h}$ to reduce the influence of sulphur. $\mathrm{H}_{2} \mathrm{O}, \mathrm{BD}$ and $\mathrm{NaOH}$ extractants were used for extracting labile DOM, DOMFe and DOM-minerals, respectively (Lalonde et al., 2012; Lopez-Sangil and Rovira, 2013).

\subsection{Analytical Methods}

90 DOC was measured using a TOC-L CPH/CPN, Shimadzu with platina used as a catalyst and detected with an infrared detector. The concentration of $\mathrm{Fe}$ was measured in high energy helium gas, using 8800 Triple Quadropole ICP-MS, Agilent Technologies Accuracy and precision of the measurements were better than 3 standard deviations of analytical stock Fe solution. The molar ratio of DOC: Fe can then be calculated. 
https://doi.org/10.5194/bg-2020-296

Preprint. Discussion started: 14 September 2020

(c) Author(s) 2020. CC BY 4.0 License.

(c) (i)

\subsubsection{UV-VIS Spectroscopy}

UV-VIS spectrum from 200 to $800 \mathrm{~nm}$ with step of $1 \mathrm{~nm}$ was measured in $5 \mathrm{~cm}$ quartz cuvette (UV - 2700, SHIMAZDU, Japan). The absorption coefficient at $254 \mathrm{~nm}$ (mathematically given as $\mathrm{SUVA}_{254}=($ Sample Absorbance - Blank Absorbance)/ path length (m)]) was normalized with the respective DOC (Absorption coefficient/DOC $\left(\mathrm{mg} \mathrm{L}^{-1}\right)$ for $\mathrm{SUVA}_{254}$ as a proxy to aromaticity (Weishaar et al., 2003). The slope ratio (SR), which is a proxy to the molecular weight, was estimated as the ratio of the slope of absorbance curve at shorter wavelength (275-295 nm) and longer wavelength (350-400 nm)(Helms et al.,

100 2008). Though the SR was originally water fractions, the ratio has been also applied to evaluate other fractions (He et al., 2016).

The presence of Fe in sample can influence the absorption coefficient at $254 \mathrm{~nm}$ (Poulin et al., 2014). Such effect of Fe on SUVA $_{254}$ was eliminated by subtracting it with the aid of a linear calibration curve between $\mathrm{A}_{254}$ and Fe concentrations (Fig. $\mathrm{S} 1$ ). The DOC for the Fe concentrations was in the range of $0.60 \pm 0.02 \mathrm{mg} \mathrm{L}^{-1}$.

\section{$105 \quad$ 2.4.2 Fluorescence spectroscopy}

Excitation and Emission Matrices (EEM) of fluorescence DOM (FDOM) were measured using a FluoroMax3 (Horiba, Japan) instrument with excitation wavelengths in the range $240-500 \mathrm{~nm}$ with a $10 \mathrm{~nm}$ increment step, and emission was 270-620 nm with an increment of $2 \mathrm{~nm}$. To compare the fluorescence intensities among fractions, the specific fluorescence intensity (SFI) was estimated as measured fluorescence intensity (R.U.) divided by DOC concentration ( $\left.\mathrm{mg} \mathrm{g}^{-1}\right)$. The concentration of Fe did not affect the SFI results due to low pH of BD extracts as was already shown before (Poulin et al., 2014) .

\subsection{Data Analysis}

Four sediment cores were sampled from the reservoir. Out from these four cores the mean values and the standard deviation of each parameters were estimated to construct a vertical profile. A Student t-test was used to estimate the significance (p < $0.05)$ of the difference between BD1 and BD2.

115 A parallel factor analysis (PARAFAC) was done in R studio (version 3.5.3) using staRdom package (Pucher et al., 2019). A 3 components model was obtained for all extractions and interpreted using the online spectral library of organic compounds in the environment OpenFluor (Murphy et al., 2014; https://openfluor.lablicate.com/), using a spectral match better than 95\%.

To determine the components that preferentially associate with the different pools of Fe oxyhydroxides extracted, we used the following Eq. (1) for selectivity, Sel (in percentage) calculated following:

120 Sel $(\%)=100 *\left(\frac{\mathrm{CF}}{\mathrm{CAS}}-1\right)$,

where where the ratio $\mathrm{C}_{\mathrm{F}} / \mathrm{C}_{\mathrm{AS}}$ is the component content in each fraction divided by the mean content of that component in all extracts. The mean was estimated from all the extraction steps for the respective component along the vertical profile. Components selectivity was thus ascertained with reference to the mean component from all extraction steps. The expression 
https://doi.org/10.5194/bg-2020-296

Preprint. Discussion started: 14 September 2020

(c) Author(s) 2020. CC BY 4.0 License.

\section{(c) (i)}

for the mean equals zero. A positive value indicates that a given extractant extracted the component more efficiently compared to the mean extractants, hence there is component selectively associated to that extractant. Conversely, a negative value of this expression indicates that the extractant extracted the respective component at a lower intensity with reference to the mean, thus the extract exhibits no selectively toward any given component.

\section{Results and Discussion}

\subsection{DOC and Fe concentrations}

130 The concentration of dissolved organic carbon (DOC) extracted by individual extractants in the sequential extraction scheme ranged between $0.8-39.3 \mathrm{mg} \mathrm{g}^{-1}$ (Fig. 2). DOC concentrations from $\mathrm{H}_{2} \mathrm{O}$ extracts were the least significant, consistently yielding low contents of dissolved or loosely bound organic carbon $\left(0.9 \pm 0.4 \mathrm{mg} \mathrm{g}^{-1}\right)$. Conversely, OH-extracted extracted most DOC, $36.3 \pm 7.4 \mathrm{mg} \mathrm{g}^{-1}$ and $22.1 \pm 7.2 \mathrm{mg} \mathrm{g}^{-1}$ in $\mathrm{OH} 1$ and $\mathrm{OH} 2$, respectively. About $13 \%$ from the total extracted, average DOC was estimated in BD extracts, $5.0 \pm 1.9 \mathrm{mg} \mathrm{g}^{-1}$ and $3.8 \pm 1.1 \mathrm{mg} \mathrm{g}^{-1}$ in BD1 and BD2, respectively. This fraction represents DOM associated to Fe oxyhydroxides (Lalonde et al., 2012; Wagai and Mayer, 2007). The corresponding Fe concentrations were $8.0 \pm 3.6 \mathrm{mg} \mathrm{g}^{-1}$ and $2.9 \pm 1.5 \mathrm{mg} \mathrm{g}^{-1}$, which results in DOC:Fe ratios of $3.0 \pm 0.4$ and $6.9 \pm 1.8$ for BD1 and BD2, respectively. (Fig. 3b-c). DOC concentrations in BD1 were statistically higher than DOC in BD2 (p < 0.002), which implies a higher affinity of OM for the active pool of Fe mineral oxyhydroxides (Fig. 3a).

Figure 3a shows that along the vertical sediment profile, the proportion of DOM bound to the active pool was significantly higher than that bound to the redox stable pool. It was observed, however, that the DOC associated with these stable phases remained unchanged along the vertical profile, whilst the DOC fraction linked to the redox active phases declined. This result implies a high reactivity, in terms of sorption and desorption, toward the sediment water interface as compared to deeper in the sediment pile. This could be linked to utilization/mineralization of fresh biomass initially associated with the active or poorly crystalline Fe-phases.

145 The co-precipitation/adsorption of DOM and Fe can be estimated by using the DOC:Fe molar ratio. However, the interpretation of this parameter regarding the degree of preservation remains ambiguous. A school of thought argues that the lower the magnitude the higher the preservation (Chen et al., 2014, 2016), whilst another argues otherwise (Han et al., 2019). Ranging between 1.2 and 10, the DOC:Fe ratios in our sediment profile (Fig. 3c) were consistent with previously reported ranges (Chen et al., 2014; Lalonde et al., 2012). The DOC:Fe for BD1 were significantly lower than BD2 (p < 0.001). DOC:Fe for BD1

150 were in the range 2.9-3.3 whilst BD2 ranged between 6.3-7.4. From this results, it is inferred that higher DOC:Fe values are associated with more stable, crystalline Fe minerals, with that pool being representative of the stabilized/preserved DOM. This is in agreement with the recent work by Han et al. (2019), which reports that comparatively higher DOC:Fe values correspond to stable OM-Fe complexes. Nonetheless, in our study site we also observed that important variations in the sediment' DOC:Fe ratio along the longitudinal profile. These can be linked to a substantial increase (4-fold) of Fe concentrations from the tributary 
https://doi.org/10.5194/bg-2020-296

Preprint. Discussion started: 14 September 2020

(c) Author(s) 2020. CC BY 4.0 License.

(c) (i)

155 to the dam. Alternatively, the longitudinal shift could be related to changes in the reactivity DOM toward excess Fe as the former change molecular size and composition during transit through the reservoir.

\subsection{UV-VIS Spectral Characteristic of Extractants}

\subsubsection{SUVA 254}

Specific ultraviolet absorbance of DOC at the $254 \mathrm{~nm}$ wavelength, $\mathrm{SUVA}_{254}$, is an index used as a proxy for aromaticity that

160 for our individual fractions ranged from 1.6 to $5.3 \mathrm{~L}(\mathrm{mg} \mathrm{C})^{-1} \mathrm{~m}^{-1}$ (Fig. 4a). Higher values correspond to the OH1 fractionextracted DOM $(5.0 \pm 2.2)$ whilst the OH2-extracted DOM has SUVA $_{254}$ values of $1.8 \pm 0.4$. With the Fe effect subtracted, both $\mathrm{H}_{2} \mathrm{O}$ ' and BD' $\mathrm{SUVA}_{254}$ values were comparable, with no significant difference in the $\mathrm{SUVA}_{254}$ values of DOM extracted by $\mathrm{BD} 1$ and BD2. In consequence, these two fractions are thought similar in their aromatic yield.

\subsubsection{Slope Ratio (SR)}

165 For individual fractions, the SR, proxy for DOM molecular weight ranged from 0.9-5.1. From the literature, SR more typically ranges from 0.4-12.0 (Helms et al., 2008; He et al., 2016). The higher the SR values the lower the molecular weight (Helms et al. 2008). Higher SR values in sequential extraction correspond to DOM extracted by BD2 (i.e., $6.0 \pm 1.7$ ), followed by BD1 (2.2 \pm 1.4). The SR of DOM extracted by $\mathrm{H}_{2} \mathrm{O}, \mathrm{OH} 1$ and $\mathrm{OH} 2$ were $1.6 \pm 0.4,1.4 \pm 0.2$ and $2.8 \pm 0.7$, respectively (Fig. 4b). Though there was no substantial difference in aromaticity of the DOM extracted by the BD1 and BD2 fractions, their SR

170 differed significantly. The SR value of DOM from BD2 in sequential extraction was significantly higher compared to that from BD1 ( $\mathrm{p}=0.01)$, meaning that BD2 extracted comparatively lower weight aromatics. This implies that the aromatic structure of the DOM extracted by the two BD steps may differ despite their similar SUVA 254 score range. Such structural difference could be ascribed to the number of aromatic rings. This result is important as it indicates that DOM associated with different redox Fe oxyhydroxide' pools vary in terms of quality and lability.

\section{3.3 EEM-PARAFAC}

Three components allowed us further elaborating on the chemical structure of the FDOM as determined from their maxima excitation and emission wavelengths in PARAFAC and interpreted by using their loadings in the openfluor model (Fig. S5). The range of intensities of these three components, namely $\mathrm{C} 1, \mathrm{C} 2$ and $\mathrm{C} 3$, are 0.1-6.0, 0.1-1.4 and 0.0-3.5 RU g mg ${ }^{-1} \mathrm{C}$, respectively (Fig. 5). The $\mathrm{H}_{2} \mathrm{O}$ fraction extracted DOM with the highest SFI in all components, which ranged from 5.9 \pm 1.3 ,

$1801.1 \pm 0.3$ and $3.3 \pm 1.0 \mathrm{RU} \mathrm{g} \mathrm{mg}^{-1} \mathrm{C}$ for $\mathrm{C} 1, \mathrm{C} 2$ and $\mathrm{C} 3$, respectively. The intensities associated to the $\mathrm{OH}$-extracted FDOM fractions were for all components $\leq 0.2 \mathrm{mg} \mathrm{g}^{-1}$. The SFI of FDOM extracted by BD1 was $0.8 \pm 0.3 \mathrm{RU} \mathrm{g} \mathrm{mg}^{-1} \mathrm{C}$ for $\mathrm{C} 1$, and $0.3 \pm 0.1 \mathrm{RU} \mathrm{g} \mathrm{mg}^{-1} \mathrm{C}$ for both $\mathrm{C} 2$ and $\mathrm{C} 3$. Finally, the FDOM extracted by BD2 was $1.0 \pm 0.4,0.3 \pm 0.1$ and $0.7 \pm 0.4 \mathrm{RU} \mathrm{g}$ $\mathrm{mg}^{-1} \mathrm{C}$ for $\mathrm{C} 1,2$ and $\mathrm{C} 3$ respectively. 
https://doi.org/10.5194/bg-2020-296

Preprint. Discussion started: 14 September 2020

(c) Author(s) 2020. CC BY 4.0 License.

\section{(c) (i)}

Table 1 listed results of openfluor database for the 3 model components. Accordingly, with an excitation to emission ratio (Ex:Em) of 240/454, Component 1 (C1) could be interpreted to be the humic-like substance fulvic acid. C1, however, also falls in the range attributed to reduced quinones (Ishii and Boyer, 2012). The longer wavelength in the emission range of C1 has been correlated to a high molecular weight and hydrophobic nature (Wu et al., 2003). The component can be sourced from both microbial and terrigenous sources (Lapierre and Frenette, 2009; Stedmon and Markager, 2005).

Component 2 (C2) has an Ex:Em of 310/394, which is generally reported as a humic-like substance exhibiting less aromatic rings and hydrophobicity and lower molecular weight than $\mathrm{C} 1$ (Wu et al., 2003). From its Ex:Em, this component is also known to possess characteristics of oxidized quinones and can be sourced either from both terrestrial and microbial organic matter (Ishii and Boyer, 2012). Finally, component 3 (C3) exhibits an Ex:Em ratio of 270/316 that can be ascribed to a proteinlike moiety. In terms of the $\mathrm{OH}$-extracted FDOM fraction, their near zero SFI values for C3 indicate that DOM associated with minerals are protected from microbial degradation ( Keil et al., 1994; Lalonde et al., 2012; Rothman and Forney, 2008).

For both BD fractions, larger variations in the vertical profile of FDOM were seen in C3. Iron oxyhydroxides are said to have higher and moderate affinity to C1 and C2 (Ishii and Boyer, 2012). It is argued that the association of DOM to oxyhydroxide phases could reduce biodegradation of the former through the formation of stronger bonds, distortion of the crystal structure of the oxyhydroxides and formation of larger molecules (Eusterhues et al., 2008; Mikutta et al., 2007). This seems to be reflected by our results as low SFI values of $\mathrm{C} 3$ from the $\mathrm{OH}$ fraction generally represent FDOM bounded to other mineral phases, such as clays or perhaps Al-hydroxides, while the DOM-Fe association extracted by the BD sequential steps had comparatively much higher C3' SFI values (Fig. 5).

The previous result and its implications to DOM preservation could also be speculatively linked to an electron shuttling intrinsic to the Fe-DOM complex. Chemolithotrophic microbes capable of conducting OM respiration process coupled to iron utilization could be using $\mathrm{C} 1$ and $\mathrm{C} 2$ as an electron donor or acceptor, especially because these components may also correspond to reduced and oxidized quinone moieties, respectively (Li et al., 2014; Orsetti et al., 2013). Under conditions of transient anoxia usually observed in aqueous settings, these components can be regenerated and recycled (Aeschbacher et al., 2011, 2012). We further elaborate on this alternative avenue for DOM preservation below.

\subsection{DOM component preferentially associated with $\mathrm{Fe}$}

The long-term preservation of DOM-Fe in sediments is generally thought to be enhanced by the irreversible reactivity of the DOM component and Fe-oxyhydroxides (Henrichs, 1995). The structure of both $\mathrm{C} 1$ and $\mathrm{C} 2$, however, possesses a redox behavior that makes their reaction with Fe-oxyhydroxide reversible leading to the solubilization of the DOM or both Fe and DOM, with the latter subsequently being biodegradable (Burdige, 2007; Keil and Mayer, 2014). Yet, C3 does not contain a redox component, and, thus, its reaction with Fe hydroxide minerals is irreversible.

A selectivity model mathematically described in Equation 1 (Section 2.5 above) was used to study the components that are

215 preferentially extracted by all the extracts, with emphasis on the sequential BD 1 and BD2 steps (Fig. 6b). It was observed 
https://doi.org/10.5194/bg-2020-296

Preprint. Discussion started: 14 September 2020

(c) Author(s) 2020. CC BY 4.0 License.

(c) (i)

that $\mathrm{C} 1$ and $\mathrm{C} 2$ were selectively extracted by BD1, which could also explain the different SR values of the BD extractions. Wu et al. (2003) observed that OM components emitting in longer wavelengths have comparatively higher molecular weight compared to those emitting in shorter wavelength. $\mathrm{C} 2$ in the first $2 \mathrm{~cm}$ of the sediment pile, however, was selectively dissolved by BD2. Conversely, $\mathrm{C} 3$ was only selectively extracted by $\mathrm{BD} 2$ and it increases with depth along the vertical profile.

From our modelling results, it could be inferred that the regenerable humic-like components $(\mathrm{C} 1$ and $\mathrm{C} 2)$ have high sorption affinity to Fe mineral oxyhydroxides i.e. both $\mathrm{C} 1$ and $\mathrm{C} 2$ react to a large extent, faster with Fe (III)-bearing minerals (e.g., Du et al., 2018) especially in the redox active pool that include the poorly crystalline oxyhydroxide phases. However, the stability of the DOM-Fe, which enhances the long-term preservation of DOM-Fe, is also influenced by $\mathrm{C} 3$ as observed in other studies (Adhikari and Yang, 2015; Lalonde et al., 2012) and this we found to rather occur in the redox stable/less active pool (BD2)

225 of the reactive Fe-oxyhydroxide mineral phases. This observation agrees with the assertion that irreversible reactions enhance the stabilization of the DOM-Fe at longer timescales. In this regard, our interpretation is at odds with Han et al. (2019) whose study also concluded that high DOC:Fe values could be an indication of stability in the DOM-Fe but concluded the OM stabilised in the association was mainly humic-like in character. The results dissimilarity could result from synthetic Feoxyhydroxides used in the latter study are not exposed to environmental conditions over an appreciable time. Further work is thus required to conclude on this as the quality of the DOM as well as its loading (DOC:Fe) might influence the dissolution kinetics (Eusterhues et al., 2014).

\section{Conclusions}

Humic-like substances of DOM were selectively associated with the redox active Fe pools whilst the stable Fe pool selectively associated with proteinaceous (non-humic) substances. As the humic-like substance is known to contain quinone moieties that makes them redox active, their binding with iron undergoes a reversible reaction whilst that is not the case for proteinaceous substances. We therefore determined that the rusty carbon sink by OM-Fe is mostly comprised of the non-humic substances of DOM and a redox stable Fe oxyhydroxides. Accordingly, this study is significant as it addresses the gap due to studying bulk Fe oxyhydroxides in DOM-Fe without distinguishing redox stability. Importantly, as indicated our results are consistent with other studies about the quality of OM stabilized in OM-Fe association, yet we achieved them by using rather simple methods. In addition, the sequential extraction used in our study gives an indication of the time scale of stability of OM-Fe when bound by humic as compared to non-humic components. Finally, by applying our characterization approach, it is possible to estimate the fate of $\mathrm{OM}$ and its role driving environmentally important cycles connected to Fe(III) as this is used as an terminal electron acceptor and thus shaping interactions between the biological, chemical, and physical processes in aqueous settings. Due to many aspects linked to global warming, upcoming changes in the source, quality, and concentration of 245 dissolved organic matter fluxes to the aquatic environment make our observations relevant for environmental characterization. Below we summarized our observations as concluding remarks: 
https://doi.org/10.5194/bg-2020-296

Preprint. Discussion started: 14 September 2020

(c) Author(s) 2020. CC BY 4.0 License.

(c) (i)

- Sequential BD1 and BD2, is vital for estimating DOM-Fe in terms of how stable or redox active Fe oxyhydroxide is which cannot be said in bulk BD extraction.

- A higher DOC:Fe molar ratio corresponds to the complex stability as shown by differences between BD1 and BD2.

- No substantial difference in $\mathrm{SUVA}_{254}$ for BD1 and BD2 indicates similar DOC character in terms of aromaticity for both fractions. However, significantly higher SR for BD2 indicates that DOC with lower molecular weight in complex with Fe increase redox stability.

- PARAFAC model of the FDOM in the different fractions indicate high reactivity of Fe toward humic components, yet the stability of the complex is given by non-humic component (C3).

255 - Humic-like substances of DOM might have high reactivity towards Fe oxyhydroxides, however the complex formed is stabilized by the non-humic substances.

\section{References}

Adhikari, D. and Yang, Y.: Selective stabilization of aliphatic organic carbon by iron oxide, Sci. Rep., 5, 1-7, 260 doi:10.1038/srep11214, 2015.

Adhikari, D., Zhao, Q., Das, K., Mejia, J., Huang, R., Wang, X., Poulson, S. R., Tang, Y., Roden, E. E. and Yang, Y.: Dynamics of ferrihydrite-bound organic carbon during microbial Fe reduction, Geochim. Cosmochim. Acta, 212, 221-233, doi:10.1016/j.gca.2017.06.017, 2017.

Aeschbacher, M., Sander, M. and Schwarzenbach, R. P.: Novel electrochemical approach to assess the redox properties of

265 humic substances, Environ. Sci. Technol., 44(1), 87-93, doi:10.1021/es902627p, 2010.

Aeschbacher, M., Vergari, D., Schwarzenbach, R. P. and Sander, M.: Electrochemical analysis of proton and electron transfer equilibria of the reducible moieties in humic acids, Environ. Sci. Technol., 45(19), 8385-8394, doi:10.1021/es201981g, 2011. Aeschbacher, M., Brunner, S. H., Schwarzenbach, R. P. and Sander, M.: Assessing the effect of Humic Acid redox state on organic pollutant sorption by combined electrochemical reduction and sorption experiments, Environ. Sci. Technol., 46(7), 3882-3890, doi:10.1021/es204496d, 2012.

Bittar, T. B., Vieira, A. A. H., Stubbins, A. and Mopper, K.: Competition between photochemical and biological degradation of dissolved organic matter from the cyanobacteria microcystis aeruginosa, Limnol. Oceanogr., 60(4), 1172-1194, doi:10.1002/lno.10090, 2015.

Borch, T., Inskeep, W. P., Harwood, J. A. and Gerlach, R.: Impact of ferrihydrite and anthraquinone-2,6-disulfonate on the 275 reductive transformation of 2,4,6-trinitrotoluene by a gram-positive fermenting bacterium, Environ. Sci. Technol., 39(18), 7126-7133, doi:10.1021/es0504441, 2005.

Burdige, D. J.: Preservation of organic matter in marine sediments: Controls, mechanisms, and an imbalance in sediment organic carbon budgets?, Chem. Rev., 107(2), 467-485, doi:10.1021/cr050347q, 2007.

Catalá, T. S., Reche, I., Fuentes-Lema, A., Romera-Castillo, C., Nieto-Cid, M., Ortega-Retuerta, E., Calvo, E., Álvarez, M., 280 Marrasé, C., Stedmon, C. A. and Álvarez-Salgado, X. A.: Turnover time of fluorescent dissolved organic matter in the dark 
https://doi.org/10.5194/bg-2020-296

Preprint. Discussion started: 14 September 2020

(c) Author(s) 2020. CC BY 4.0 License.

\section{(c) (i)}

global ocean, Nat. Commun., 6, doi:10.1038/ncomms6986, 2015.

Chen, C., Dynes, J. J., Wang, J. and Sparks, D. L.: Properties of Fe-organic matter associations via coprecipitation versus adsorption, Environ. Sci. Technol., 48(23), 13751-13759, doi:10.1021/es503669u, 2014.

Chen, K. Y., Chen, T. Y., Chan, Y. T., Cheng, C. Y., Tzou, Y. M., Liu, Y. T. and Teah, H. Y.: Stabilization of natural organic matter by short-range-order Iron hydroxides, Environ. Sci. Technol., 50(23), 12612-12620, doi:10.1021/acs.est.6b02793, 2016.

Du, Y., Ramirez, C. E. and Jaffé, R.: Fractionation of Dissolved Organic Matter by Co-Precipitation with Iron: Effects of Composition, Environ. Process., 5(1), 5-21, doi:10.1007/s40710-017-0281-4, 2018.

Eusterhues, K., Wagner, F. E., Häusler, W., Hanzlik, M., Knicker, H., Totsche, K. U., Kögel-Knabner, I. and Schwertmann, U.: Characterization of ferrihydrite-soil organic matter coprecipitates by X-ray diffraction and Mössbauer spectroscopy, Environ. Sci. Technol., 42(21), 7891-7897, doi:10.1021/es800881w, 2008.

Eusterhues, K., Hädrich, A., Neidhardt, J., Küsel, K., Keller, T. F., Jandt, K. D. and Totsche, K. U.: Reduction of ferrihydrite with adsorbed and coprecipitated organic matter: Microbial reduction by Geobacter bremensis vs. abiotic reduction by Nadithionite, Biogeosciences, 11(18), 4953-4966, doi:10.5194/bg-11-4953-2014, 2014.

295 Garg, S., Jiang, C. and David Waite, T.: Mechanistic insights into iron redox transformations in the presence of natural organic matter: Impact of pH and light, Geochim. Cosmochim. Acta, 165, 14-34, doi:10.1016/j.gca.2015.05.010, 2015.

Gonçalves-Araujo, R., Granskog, M. A., Bracher, A., Azetsu-Scott, K., Dodd, P. A. and Stedmon, C. A.: Using fluorescent dissolved organic matter to trace and distinguish the origin of Arctic surface waters, Sci. Rep., 6(June), 1-12, doi:10.1038/srep33978, 2016.

300 Hambly, A. C., Arvin, E., Pedersen, L. F., Pedersen, P. B., Seredyńska-Sobecka, B. and Stedmon, C. A.: Characterising organic matter in recirculating aquaculture systems with fluorescence EEM spectroscopy, Water Res., 83, 112-120, doi:10.1016/j.watres.2015.06.037, 2015.

Han, L., Sun, K., Keiluweit, M., Yang, Y., Yang, Y., Jin, J., Sun, H., Wu, F. and Xing, B.: Mobilization of ferrihydriteassociated organic carbon during Fe reduction: Adsorption versus coprecipitation, Chem. Geol., 503(November 2018), 61-68, doi:10.1016/j.chemgeo.2018.10.028, 2019.

He, W., Jung, H., Lee, J. H. and Hur, J.: Differences in spectroscopic characteristics between dissolved and particulate organic matters in sediments: Insight into distribution behavior of sediment organic matter, Sci. Total Environ., 547, 1-8, doi:10.1016/j.scitotenv.2015.12.146, 2016.

Helms, J. R., Stubbins, A., Ritchie, J. D., Minor, E. C., Kieber, D. J. and Mopper, K.: Absorption spectral slopes and slope ratios as indicators of molecular weight, source, and photobleaching of chromophoric dissolved organic matter (Limnology and Oceanography 53 955-969), Limnol. Oceanogr., 53(3), 955-969, doi:10.4319/lo.2009.54.3.1023, 2008.

Henrichs, S. M.: Sedimentary organic matter preservation: an assessment and speculative synthesis, Mar. Chem., 49(2-3), 81115, doi:10.1016/0304-4203(95)00008-F, 1995.

Ishii, S. K. L. and Boyer, T. H.: Behavior of reoccurring parafac components in fluorescent dissolved organic matter in natural 
https://doi.org/10.5194/bg-2020-296

Preprint. Discussion started: 14 September 2020

(c) Author(s) 2020. CC BY 4.0 License.

(c) (i)

315 and engineered systems: A critical review, Environ. Sci. Technol., 46(4), 2006-2017, doi:10.1021/es2043504, 2012.

Jan, J., Borovec, J., Kopáček, J. and Hejzlar, J.: Assessment of phosphorus associated with Fe and Al (hydr)oxides in sediments and soils, J. Soils Sediments, 15(7), 1620-1629, doi:10.1007/s11368-015-1119-1, 2015.

Kaiser, K. and Guggenberger, G.: The role of DOM sorption to mineral surfaces in the preservation of organic matter in soils, Org. Geochem., 31(7-8), 711-725, doi:10.1016/S0146-6380(00)00046-2, 2000.

320 Keil, R. G. and Mayer, L. M.: Mineral matrices and organic matter, in Treaties on Geochemistry 2nd Edition, edited by H. D. Hollad and K. K. Turekian, pp. 337-359, Elsevier, Oxford., 2014.

Keil, R. G., Montluçon, D. B., Prahl, F. G. and Hedges, J. I.: Sorptive preservation of labile organic matter in marine sediments, Nature, 370(6490), 549-552, doi:10.1038/370549a0, 1994.

Kellerman, A. M., Kothawala, D. N., Dittmar, T. and Tranvik, L. J.: Persistence of dissolved organic matter in lakes related to

325 its molecular characteristics, Nat. Geosci., 8(6), 454-457, doi:10.1038/NGEO2440, 2015.

Klapper, L., McKnight, D. M., Fulton, J. R., Blunt-Harris, E. L., Nevin, K. P., Lovley, D. R. and Hatcher, P. G.: Fulvic acid oxidation state detection using fluorescence spectroscopy, Environ. Sci. Technol., 36(14), 3170-3175, doi:10.1021/es0109702, 2002 .

Klüpfel, L., Piepenbrock, A., Kappler, A. and Sander, M.: Humic substances as fully regenerable electron acceptors in 330 recurrently anoxic environments, , 7(February), 195-200, doi:10.1038/NGEO2084, 2014.

Kothawala, D. N., Stedmon, C. A., Müller, R. A., Weyhenmeyer, G. A., Köhler, S. J. and Tranvik, L. J.: Controls of dissolved organic matter quality: Evidence from a large-scale boreal lake survey, Glob. Chang. Biol., 20(4), 1101-1114, doi:10.1111/gcb.12488, 2014.

Kowalczuk, P., Durako, M. J., Young, H., Kahn, A. E., Cooper, W. J. and Gonsior, M.: Characterization of dissolved organic 335 matter fluorescence in the South Atlantic Bight with use of PARAFAC model: Interannual variability, Mar. Chem., 113(3-4), 182-196, doi:10.1016/j.marchem.2009.01.015, 2009.

Lalonde, K., Mucci, A., Ouellet, A. and Gélinas, Y.: Preservation of organic matter in sediments promoted by iron, Nature, 483(7388), 198-200, doi:10.1038/nature10855, 2012.

Lapierre, J. F. and Frenette, J. J.: Effects of macrophytes and terrestrial inputs on fluorescent dissolved organic matter in a 340 large river system, Aquat. Sci., 71(1), 15-24, doi:10.1007/s00027-009-9133-2, 2009.

Li, X., Liu, T., Liu, L. and Li, F.: Dependence of the electron transfer capacity on the kinetics of quinone-mediated Fe(iii) reduction by two iron/humic reducing bacteria, RSC Adv., 4(5), 2284-2290, doi:10.1039/c3ra45458d, 2014.

Lopez-sangil, L. and Rovira, P.: Soil Biology \& Biochemistry Sequential chemical extractions of the mineral-associated soil organic matter: An integrated approach for the fractionation of organo-mineral complexes, Soil Biol. Biochem., 62, 57-67, 345 doi:10.1016/j.soilbio.2013.03.004, 2013.

Mikutta, R., Mikutta, C., Kalbitz, K., Scheel, T., Kaiser, K. and Jahn, R.: Biodegradation of forest floor organic matter bound to minerals via different binding mechanisms, Geochim. Cosmochim. Acta, 71(10), 2569-2590, doi:10.1016/j.gca.2007.03.002, 2007. 
https://doi.org/10.5194/bg-2020-296

Preprint. Discussion started: 14 September 2020

(c) Author(s) 2020. CC BY 4.0 License.

\section{(c) (i)}

Murphy, K. R., Stedmon, C. A., Wenig, P. and Bro, R.: OpenFluor- An online spectral library of auto-fluorescence by organic compounds in the environment, Anal. Methods, 6(3), 658-661, doi:10.1039/c3ay41935e, 2014.

Neff, J. C. and Asner, G. P.: Dissolved organic carbon in terrestrial ecosystems: Synthesis and a model, Ecosystems, 4(1), 2948, doi:10.1007/s100210000058, 2001.

Nierop, K. G. J., Jansen, B. and Verstraten, J. M.: Dissolved organic matter, aluminium and iron interactions: Precipitation induced by metal/carbon ratio, $\mathrm{pH}$ and competition, Sci. Total Environ., 300(1-3), 201-211, doi:10.1016/S00489697(02)00254-1, 2002.

Orsetti, S., Laskov, C. and Haderlein, S. B.: Electron transfer between iron minerals and quinones: Estimating the reduction potential of the Fe(II)-goethite surface from AQDS speciation, Environ. Sci. Technol., 47(24), 14161-14168, doi:10.1021/es403658g, 2013.

Osburn, C. L., Boyd, T. J., Montgomery, M. T., Bianchi, T. S., Coffin, R. B. and Paerl, H. W.: Optical proxies for terrestrial dissolved organic matter in estuaries and coastal waters, Front. Mar. Sci., 2(JAN), 1-11, doi:10.3389/fmars.2015.00127, 2016. Poulin, B. A., Ryan, J. N. and Aiken, G. R.: Effects of iron on optical properties of dissolved organic matter, Environ. Sci. Technol., 48(17), 10098-10106, doi:10.1021/es502670r, 2014.

Pucher, M., Wünsch, U., Weigelhofer, G., Murphy, K., Hein, T. and Graeber, D.: staRdom: Versatile Software for Analyzing Spectroscopic Data of Dissolved Organic Matter in R, Water, 11(11), 2366, doi:10.3390/w11112366, 2019.

Rothman, D. H. and Forney, D. C.: Response to comment on "Physical model for the decay and preservation of marine organic carbon," Science (80-. )., 319(5870), 1325-1329, doi:10.1126/science.1148678, 2008.

Schittich, A. R., Wünsch, U. J., Kulkarni, H. V., Battistel, M., Bregnhøj, H., Stedmon, C. A. and McKnight, U. S.: Investigating Fluorescent Organic-Matter Composition as a Key Predictor for Arsenic Mobility in Groundwater Aquifers, Environ. Sci. Technol., 52(22), 13027-13036, doi:10.1021/acs.est.8b04070, 2018.

370 Scott, D. T., Mcknight, D. M., Blunt-Harris, E. L., Kolesar, S. E. and Lovley, D. R.: Quinone moieties act as electron acceptors in the reduction of humic substances by humics-reducing microorganisms, Environ. Sci. Technol., 32(19), 2984-2989, doi:10.1021/es980272q, 1998.

Shutova, Y., Baker, A., Bridgeman, J. and Henderson, R. K.: Spectroscopic characterisation of dissolved organic matter changes in drinking water treatment: From PARAFAC analysis to online monitoring wavelengths, Water Res., 54, 159-169, doi:10.1016/j.watres.2014.01.053, 2014.

Stedmon, C. A. and Markager, S.: Resolving the variability in $\{\mathrm{DOM}\}$ fluorescence in a temperate estuary and its catchment unsing \{PARAFAC\}, Limnol.Oceanogr., 50(2), 686-697, 2005.

Struyk, Z. and Sposito, G.: Redox properties of humic acids, Geoderma, 102(3-4), 329-346, 2001.

Torn, M. S., Trumbore, S. E., Chadwick, O. A., Vitousek, P. M. and Hendricks, D. M.: Mineral control of soil organic carbon 380 storage and turnover, Nature, 389(6647), 170-173, doi:10.1038/38260, 1997.

Wagai, R. and Mayer, L. M.: Sorptive stabilization of organic matter in soils by hydrous iron oxides, Geochim. Cosmochim. Acta, 71(1), 25-35, doi:10.1016/j.gca.2006.08.047, 2007. 
https://doi.org/10.5194/bg-2020-296

Preprint. Discussion started: 14 September 2020

(c) Author(s) 2020. CC BY 4.0 License.

(c) (1)

Weishaar, J. L., Aiken, G. R., Bergamaschi, B. A., Fram, M. S., Fujii, R. and Mopper, K.: Evaluation of specific ultraviolet absorbance as an indicator of the chemical composition and reactivity of dissolved organic carbon, Environ. Sci. Technol.,

385 37(20), 4702-4708, doi:10.1021/es030360x, 2003.

Wu, F. C., Evans, R. D. and Dillon, P. J.: Separation and characterization of NOM by high-performance liquid chromatography and on-line three-dimensional excitation emission matrix fluorescence detection, Environ. Sci. Technol., 37(16), 3687-3693, doi:10.1021/es020244e, 2003.

Xiao, Y. H., Hoikkala, L., Kasurinen, V., Tiirola, M., Kortelainen, P. and Vähätalo, A. V.: The effect of iron on the

390 biodegradation of natural dissolved organic matter, J. Geophys. Res. Biogeosciences, 121(10), 2544-2561, doi:10.1002/2016JG003394, 2016.

Yamashita, Y., Scinto, L. J., Maie, N. and Jaffé, R.: Dissolved Organic Matter Characteristics Across a Subtropical Wetland's Landscape: Application of Optical Properties in the Assessment of Environmental Dynamics, Ecosystems, 13(7), 1006-1019, doi:10.1007/s10021-010-9370-1, 2010.

395 van der Zee, C., Roberts, D. R., Rancourt, D. G. and Slomp, C. P.: Nanogoethite is the dominant reactive oxyhydroxide phase in lake and marine sediments, Geology, 31(11), 993-996, doi:10.1130/G19924.1, 2003.
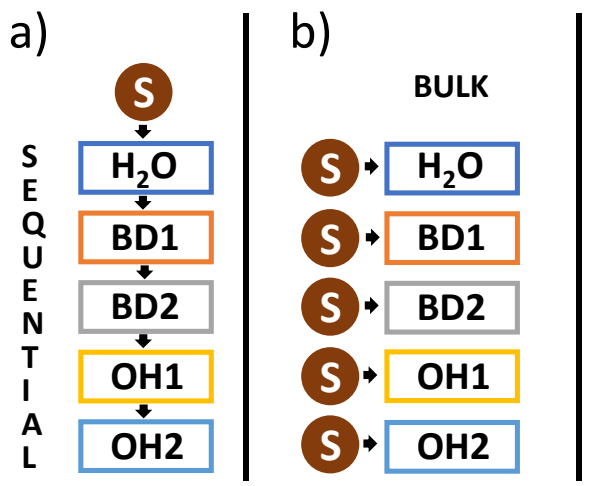

Legend

S - sediment sample

\begin{tabular}{ll|l}
$\mathrm{H}_{2} \mathrm{O}-$ deoxygeneted $\mathrm{H}_{2} \mathrm{O}$ & $10 \mathrm{~min}$ \\
\hline $\mathrm{BD} 1$ & $-0.1 \mathrm{M} \mathrm{Na}_{2} \mathrm{~S}_{2} \mathrm{O}_{4}+0.1 \mathrm{M} \mathrm{NaHCO}_{3}, \mathrm{pH}^{\sim} 7.2$ & $10 \mathrm{~min}$ \\
\hline $\mathrm{BD} 2$ & $-0.1 \mathrm{M} \mathrm{Na}_{2} \mathrm{~S}_{2} \mathrm{O}_{4}+0.1 \mathrm{M} \mathrm{NaHCO}_{3}, \mathrm{pH}^{\sim} 7.2$ & $2 \mathrm{~h}$ \\
\hline $\mathrm{OH} 1$ & $-1 \mathrm{M} \mathrm{NaOH}$ & $10 \mathrm{~min}$ \\
\hline $\mathrm{OH} 2-1 \mathrm{M} \mathrm{NaOH}$ & $16 \mathrm{~h}$
\end{tabular}

Fig. 1. Scheme for sequential (a) and bulk (b) extractions. The legend describes the composition of extractants and extraction times. 
https://doi.org/10.5194/bg-2020-296

Preprint. Discussion started: 14 September 2020

(c) Author(s) 2020. CC BY 4.0 License.

(c) (i)

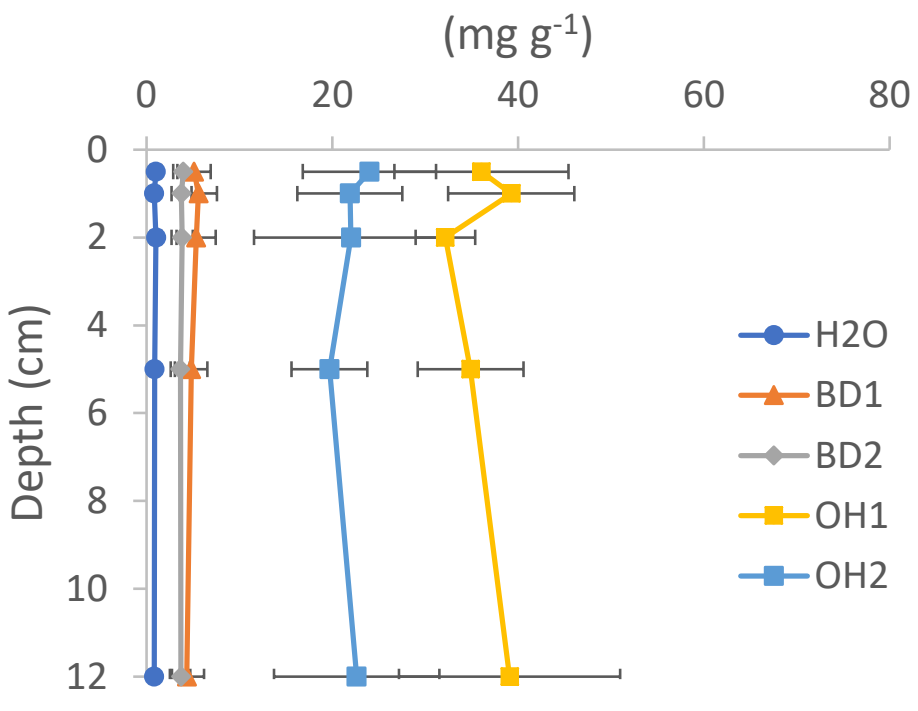

Fig. 2. Mean concentrations of extracted DOC from sequential extraction. Values are relevant to means and SD of four sediment cores along the vertical profile of Landstejn reservoir. 
https://doi.org/10.5194/bg-2020-296

Preprint. Discussion started: 14 September 2020

(c) Author(s) 2020. CC BY 4.0 License.

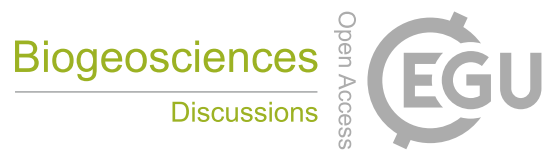

(c) (1)

a) DOC - sequential

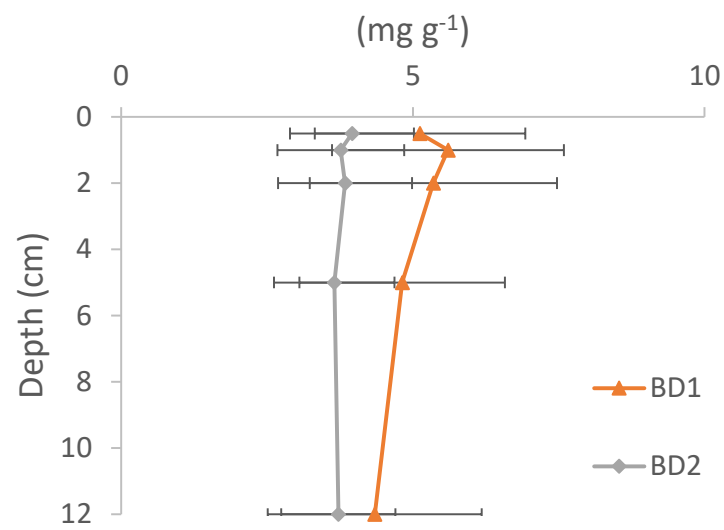

b) $\mathrm{Fe}$ - sequential

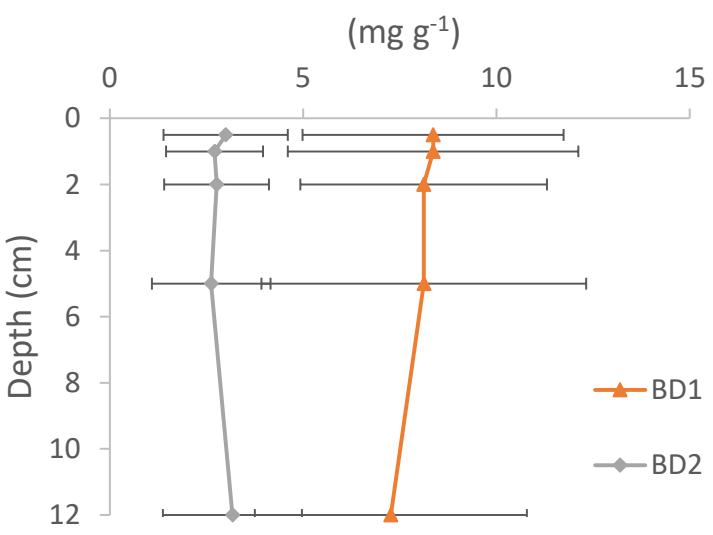

c) molar DOC:Fe - sequential

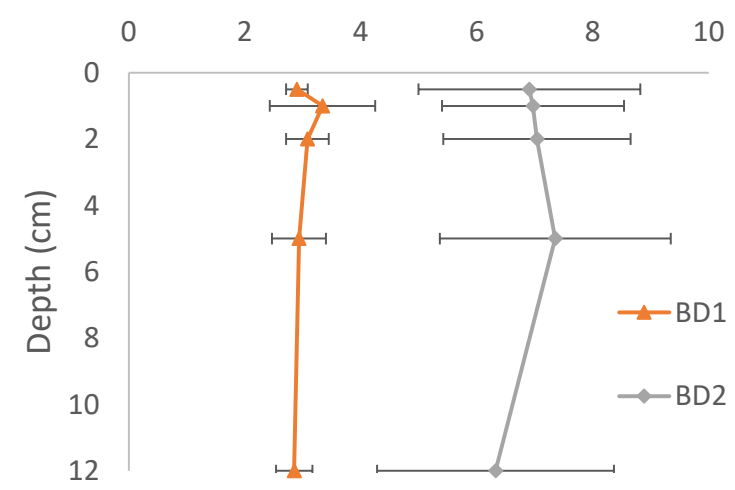

405 Fig. 3. Concentrations of DOC extracted by BD1 and BD2 in sequential (a), and Fe extracted by BD1 and BD2 (b) and molar ratios of DOC and Fe extracted by BD1 and BD2 in a sequential scheme (c). Values are relevant to means and SD of four sediment cores along the vertical profile of Landstejn reservoir. 


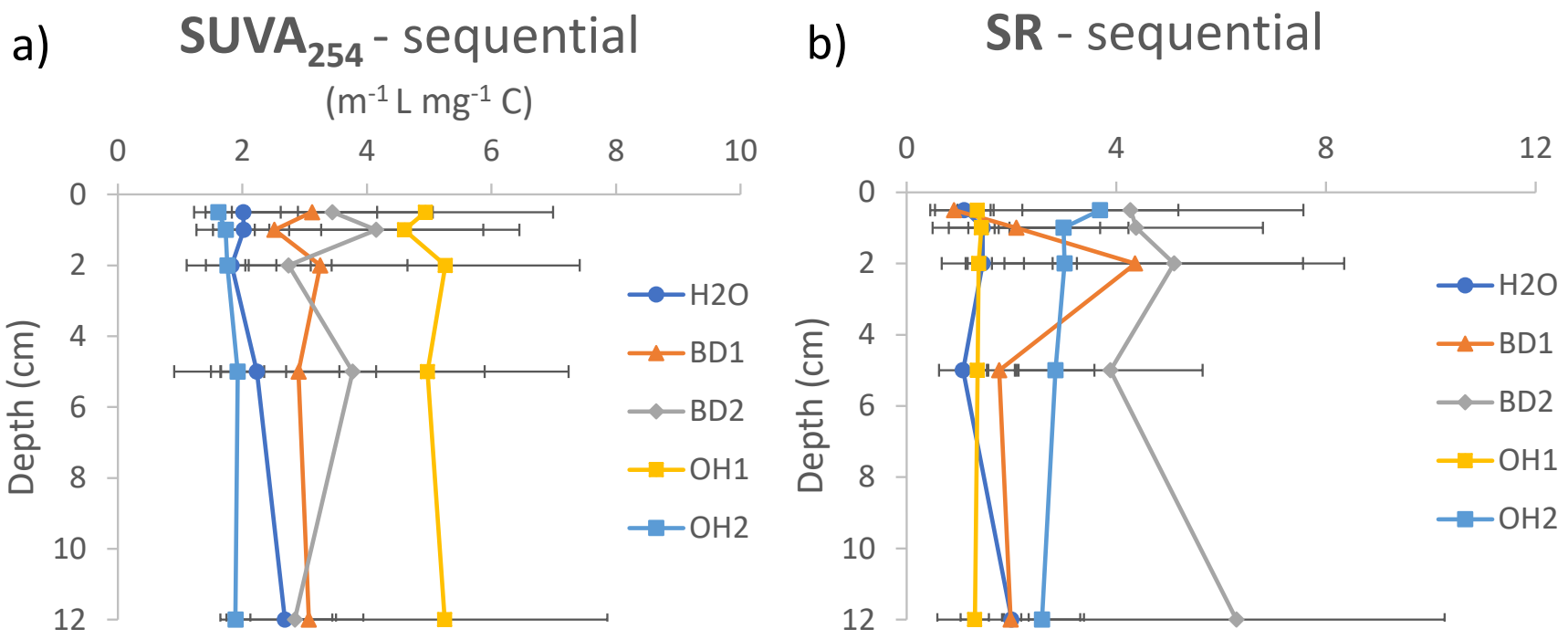

410 Fig. 4. Values of SUVA 254 used as a proxy to aromaticity (a) and SR proxy to molecular weight (b) for individual sequential extractions. Values are relevant to means and SD of four sediment cores along the vertical profile of Landstejn reservoir. 
https://doi.org/10.5194/bg-2020-296

Preprint. Discussion started: 14 September 2020

(c) Author(s) 2020. CC BY 4.0 License.

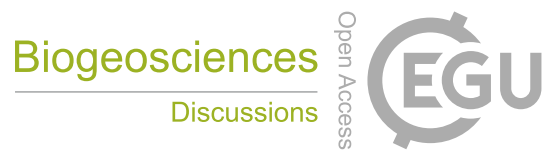

(c) (1)

C1 - sequential

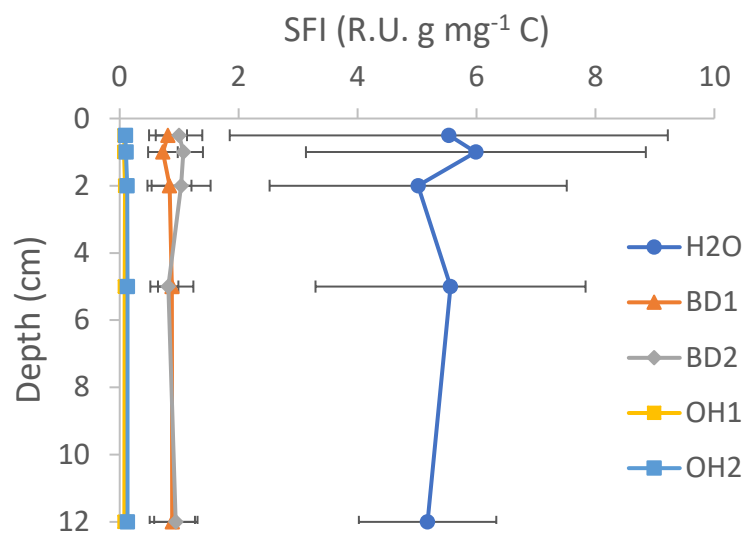

C2 - sequential

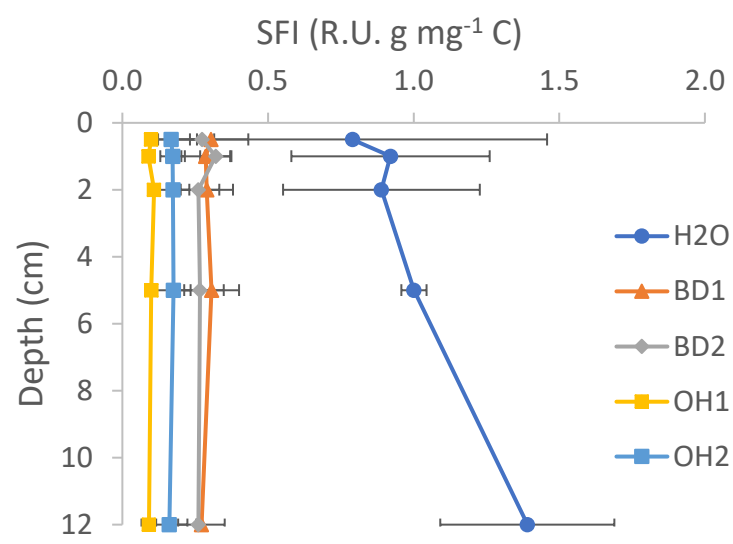

C3 - sequential

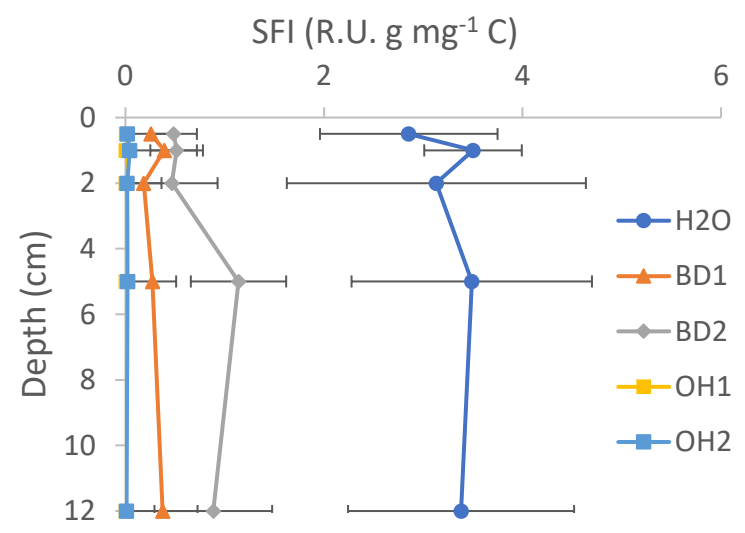

Fig. 5. Specific fluorescence intensities-SFI (given as the ratio of the fluorescence intensity in R. U. to the DOC concentration in mg $\left.\mathrm{g}^{-1}\right)$ of identified components $(\mathrm{C} 1, \mathrm{C} 2$ and $\mathrm{C} 3)$ for individual extracts in sequential extraction scheme. Values are relevant to means and SD of four sediment cores along the vertical profile of Landstejn reservoir. 
https://doi.org/10.5194/bg-2020-296

Preprint. Discussion started: 14 September 2020

(c) Author(s) 2020. CC BY 4.0 License.

a)

Components mean proportion

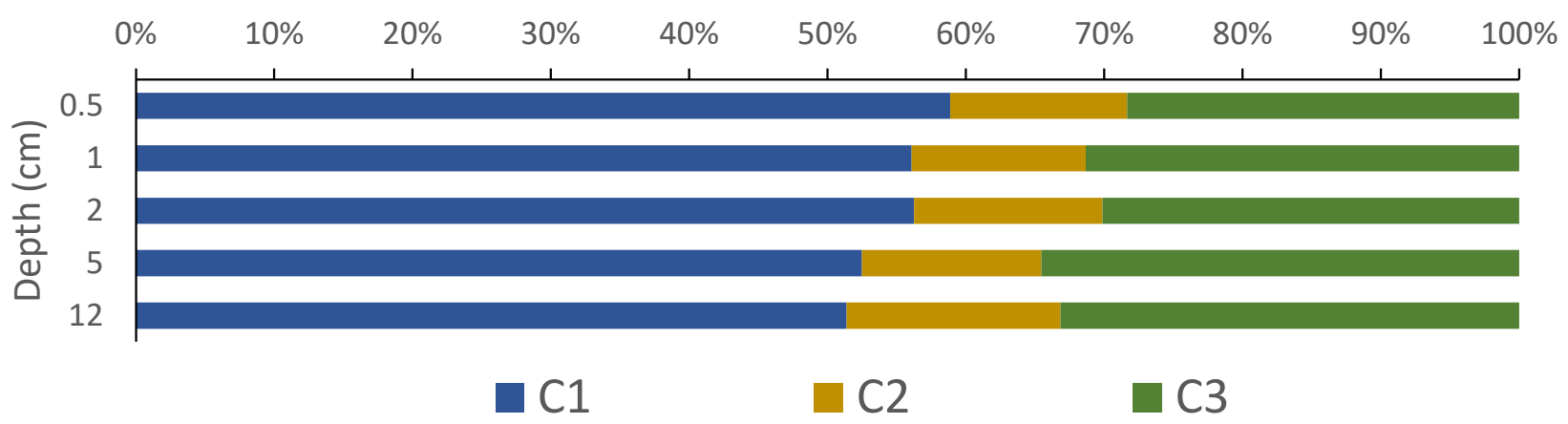

b) BD1

BD2
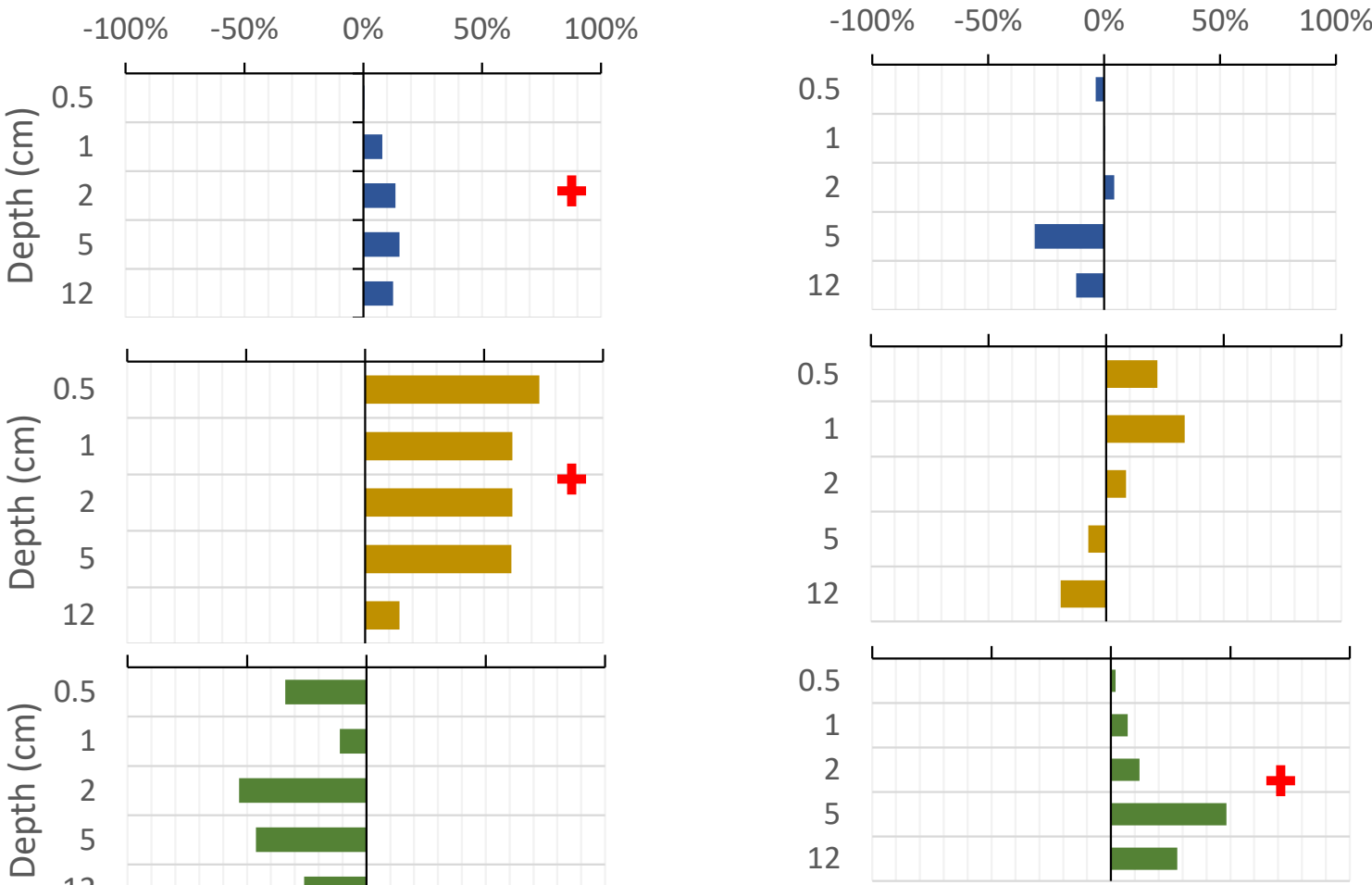

Fig. 6. Mean proportions of the different PARAFAC components $(\mathrm{C} 1, \mathrm{C2}, \mathrm{C3})$ from all extracts in sequential extractions along the vertical profile of four sediment cores (a) and a selectivity model for sequential BD1 and BD2 (b). The selectivity model shows relative changes against the mean of all extractants with positive values $(+)$ indicating preferential association of particular components in BD1 or BD2. 
https://doi.org/10.5194/bg-2020-296

Preprint. Discussion started: 14 September 2020

(c) Author(s) 2020. CC BY 4.0 License.

(c) (i)

Table 1. Summary of PARAFAC model component from openfluor database, similarity score of identified components with respect to cited studies and their description.

\begin{tabular}{|c|c|c|c|}
\hline Comp. & $\begin{array}{l}\text { Simi- } \\
\text { larity } \\
\text { score }\end{array}$ & References & Description \\
\hline C1 & 0.99 & Osburn et al., (2016) & - fulvic acids \\
\hline Max Ex/Em & 0.99 & Shutova et al., (2014) & - presence and origin mainly in terrigenous environment \\
\hline \multirow{2}{*}{$240 / 454$} & 0.99 & Bittar et al., (2015) & - also observed to be autochthonously sourced \\
\hline & 0.99 & Gonçalves-Araujo et al., (2016) & \\
\hline C2 & 0.99 & Hambly et al., (2015) & - humic materials processed by microbial activity \\
\hline Max Ex/Em & 0.99 & Kothawala et al., (2014) & - sourced both in terrigenous and aquatic systems \\
\hline \multirow{2}{*}{$310 / 394$} & 0.99 & Schittich et al., (2018) & \\
\hline & 0.99 & Kowalczuk et al., (2009) & \\
\hline $\mathrm{C3}$ & 0.97 & Bittar et al., (2015) & - protein like components \\
\hline Max Ex/Em & 0.96 & Catalá et al., (2015) & - mainly autochthonously sourced \\
\hline $270 / 31$ & 0.98 & Yamashita et al., (2010) & \\
\hline
\end{tabular}

